\title{
Prawo i geneza porządku politycznego $w$ teologii politycznej Richarda Hookera
}

\author{
Abstract \\ The Law and the Origins of Political Order in Richard Hooker's Political \\ Theology
}

Richard Hooker was one of the most important English theologians and political thinkers of the $16^{\text {th }}$ century. He is regarded as the originator of Anglicanism and the greatest adversary of Puritan extremists. His fundamental work The Lawes of Ecclesiastical Politie is a repudiation of both the key principles of Puritanism (as formulated by Thomas Cartwright and William Travers) and the doctrine of Rome. While Roman Catholics put the Scripture and tradition on a parity as the touchstone of belief and the Puritans would have no authority but the Bible this article argues that Hooker steered clear of either extreme. His formula was to accept the Scripture's absolute authority where it spoke plainly and unequivocally and to consult the tradition the church on those points the Bible was silent or ambiguous. However, the solution would be incomplete without human reason, which, he insists, must be used and obeyed whenever Scripture and tradition needed clarification or were faced with a new set of circumstances. So his legal philosophy, rooted in Aquinas' theology and a reformed concept of justification, relies on the combined guidance of Revelation, tradition and reason.

Keywords: Hooker, Anglicanism, law of nature, Puritanism.

Slowa kluczowe: Hooker, anglikanizm, prawo natury, purytanizm.

\section{Wstęp}

Panowanie Elżbiety I już od początku zostało zdefiniowane rozdzierającymi królestwo antagonizmami religijnymi, każda bowiem z denominacji żywiła oczekiwania i obawy związane z rządami nowego władcy. $Z$ jednej strony byli więc katolicy, których nadzieje zostały pogrzebane wraz z bezpotomną śmiercią Marii, z drugiej anglikanie zachowujący wierność kościołowi narodowemu, w końcu istniały też liczne sekty, które sprzeciwiały się samej idei Kościoła państwowego. W ramach samego Kościoła anglikańskiego istniał jednak silny i mający wpływy także wśród hierarchii, w Izbie Gmin i na uniwer- 
sytetach ruch dążący do doprowadzenia reformacji do końca zgodnie z kontynentalnymi wzorami. W tym niebezpiecznym religijnym tyglu Elżbieta musiała dokonać wyboru drogi, którą będzie podążać Anglia, i wobec tego, że nie była znana z przesadnej pobożności, wybrała tę wskazaną przez ojca, czyniąc z Kościoła jedną z instytucji państwa, podporządkowaną jej woli. Tym samym weszła z konflikt z tymi, którzy, całkowicie ignorując unikalne angielskie warunki, uznali, że jeśli coś jest dobre dla Genewy, to równie dobrze sprawdzi się w ich ojczyźnie ${ }^{1}$. Przesiąknięci podczas swego wygnania za rządów Marii radykalnymi kontynentalnymi ideami rzucili tym samym wyzwanie królowej, stając się ośrodkiem opozycji wobec jej polityki eklezjalnej i samej teorii legitymacji władzy monarszej.

Jądrem purytańskiej argumentacji teologicznej i politycznej była bowiem dobrowolność przynależności do Kościoła wynikająca z koncepcji Przymierza ${ }^{2}$. W przekładzie Biblii Genewskiej Tyndale'a z 1532 roku hebrajski termin brit i grecki diatheke przetłumaczono bowiem jako covenant ${ }^{3}$, dzięki czemu purytanie dokonali przełożenia języka Przymierza na język polityki, chcąc zaaplikować starotestamentowe prawdy do porządku społecznego. Wedle nich wszystkie relacje społeczne - między Bogiem i człowiekiem, pastorami i zgromadzeniem, sędziami i członkami ich społeczności, miedzy członkami rodzin - były definiowane w terminach umowy lub przymierza, które polega na zgodzie i wzajemnej odpowiedzialności. Dobrowolność ta i będący jej istotą woluntaryzm prowadziły równocześnie do wniosku, że organizacja kościelna i relacje pomiędzy władzą a poddanymi powinny być oparte na tych samych zasadach. Purytanie w wieku XVI, jeszcze co prawda nieśmiało, domagali się oparcia władzy państwowej, wzorem biblijnym, na dobrowolnej umowie pomiędzy panującym a poddanymi, co więcej - radykałowie uważali, że władzę ma sprawować nie monarcha, lecz reprezentujący lud Parlament (w którym oczywiście mieli większość). Z takiego źródła politycznego zobowiązania wywodzili ponadto koncepcję prawa oporu.

W najbardziej wyrazistej formie przedstawił ją jeden z ojców szkockiej reformacji - John Knox. Choć jego poglądy początkowo nie były radykalne, to po wstąpieniu na tron królowej Marii zmienił, w wyniku wydarzeń politycznych, jak większość protestanckich myślicieli, swe podejście do zagadnienia oporu i tyranobójstwa. Jego argument opiera się na twierdzeniu, że choć każda władza pochodzi od Boga, to jest umieszczona nie tylko w królu, lecz także w jego urzędnikach. Ich władza wypływa z tego samego źródła co władza króla i, tak jak on, mają oni obowiązek zreformować religię zgodnie z prawem Bożym. Takimi urzędnikami w Szkocji jest dla Knoxa szlachta, która „ma legalną władzę ustanowioną przez Boga”4. Im także powierzył Bóg prawo miecza, by ochraniali niewinnych i karali złoczyńców ${ }^{5}$. Na równi z księciem dzierżą więc miecz sprawiedliwości i muszą wykonywać swą funkcję nawet, gdy zaniedbuje ją

1 R. Bayne, Editor's Prolegomena [w:] R. Hooker, Of the Laws of Ecclesiastical Polity. The Fifth Book, Macmillan, New York 1902, s. lvii.

2 P. Miller, Errand into the Wilderness, Harvard University Press, Cambridge 1956, s. 48-49; D. Zaret, The Heavenly Contract Ideology and Organisationon in Pre-Revolutionary Puritanism, The University of Chicago Press, Chicago 1985, s. 130-136, 167-168.

3 D.J. Lazar, Covenant and Commonwealth. From Christian Separation through the Protestant Reformation. The Covenant Tradition in Politics, Transaction Publisher, New Brunswick 1998, s. 231.

4 J. Knox, On Rebelion, Cambridge University Press, Cambridge 1994, s. 72.

5 Ibidem, s. 85. 
władza zwierzchnia. Książęta i urzędnicy państwowi nie są bowiem powołani po to, by sprawować tyrańską władzę nad ludem, lecz są ustanowieni przez Boga, by dbać o tego ludu pomyślność i pożytek. Gdy władca sprzeniewierzy się tej funkcji, gdy zwalcza prawdziwą religię, działa przeciwko Bożej chwale i swoim braciom, jego działania nie mają już boskiej sankcji, a poddani są zwolnieni z obowiązku posłuchu ${ }^{6}$. Gdy tak się dzieje, niżsi urzędnicy powinni bronić Bożego prawa, wykonując Boży rozkaz, który nakazuje wypowiedzenie posłuszeństwa bezbożnemu tyranowi ${ }^{7}$. Stąd protestant nie może być lojalnym poddanym katolickiego władcy, dla Knoxa bowiem papież to Antychryst, a katolicyzm to zbiór błędów, które nie znajdują uzasadnienia w Piśmie ${ }^{8}$. Teoria ta stała się podstawą rewolucji religijnej w Szkocji, nic dziwnego zatem, że Elżbieta I w oczach Knoxa i reszty fanatyków była niewiele lepsza od Marii Tudor i Marii Stuart, zwłaszcza że Knox podczas swego wygnania na kontynencie poznał takich prominentnych przedstawicieli angielskich wspólnot protestanckich jak biskup Coverdale, biskup Bale, John Fox czy William Whittigham. Tam też mógł zapoznać ich ze swymi teoriami i to między innymi jemu angielski purytanizm zawdzięcza tak radykalną zmianę ideologicznego oblicza. Zaledwie bowiem jedno pokolenie dzieli umiarkowane Obedience of a Christian Man Tyndale'a od rewolucyjnych traktatów Poneta i Goodmana ${ }^{10}$. Sama Elżbieta dostrzegała te destrukcyjne konsekwencje purytanizmu i, jak się wkrótce okazało, to nie biskupi anglikańscy, lecz ona stała się jego największym wrogiem. Dlatego już na początku rządów zakazała wszelkich kazań w królestwie, by zapobiec gwałtownej kalwińskiej agitacji religijnej, następnie zaś w roku 1559 Parlament z pominięciem Konwokacji - oficjalnego organu Kościoła - nie bez dyskusji i oporu"11 uchwalił Akt supremacji, który czynił Elżbietę ,jedynym najwyższym rządcą tego królestwa i wszystkich innych dominiów i krajów jej wysokości, tak we wszystkich rzeczach i sprawach duchowych i kościelnych, jak i świeckich"12, oddając jej, tak jak wcześniej jej ojcu, władzę nad Kościołem anglikańskim. Stąd nie tylko urzędnicy królewscy, absolwenci uniwersytetów i sędziowie, lecz również duchowni musieli składać nań przysięgę pod groźbą utraty urzędu, a trzykrotne jego zanegowanie „w piśmie, druku, nauczaniu, kaznodziejstwie, w słowie, w czynie lub działaniu, celowo, złośliwie i bezpośrednio"13 groziło śmiercią za zdradę stanu. Równocześnie Akt uniformizacji przywrócił z pewnymi zmianami Modlitewnik (Book of Common Prayer) z czasów Edwarda VI. W roku 1563 Konwokacja uchwaliła Trzydzieści dziewięć artykutów określających doktrynalne fundamenty Kościoła anglikańskiego, będących w istocie teologicznym kompromisem

6 J. Knox, History of the Reformation in Scotland, Blackie \& Son, Glasgow 1841, s. 203-205.

7 T. M'Crie, John Knox: Containing Illustrations of the History of the Reformation in Scotland, William Balckwood, Edinburgh 1831, s. 123-124.

8 J. Broome, John Knox, Gospel Standard Publications, Roundwood Lane 1994, s. 2.

9 P. Lorimer, John Knox and the Church of England: His Work in Her Pulpit and His Influence Upon Her Liturgy Articles and Parties, Kessinger Publishing, Whitefish 2004, s. 2.

${ }_{10}$ H. Laski, Introduction [w:] Junius Brutus, A Defence of Liberty Against Tyrants. A Translation of the Vindiciae Contra Tyrannos, G. Bell \& Sons, London 1924, s. 4.

11 J.E. Neale, The Elizabethan Acts of Supremacy and Uniformity, „The English Historical Review” 1950, vol. 65, no. 256 (July), s. 304-332.

12 Elizabeth's Supremacy Act, Restoring Ancient Jurisdiction (1559) [w:] Documents Illustrative of English Church History, wyd. H. Gee, W.J. Hardy, Macmillan, New York 1896, s. 450.

13 Ibidem, s. 453. 
pomiędzy katolicyzmem i kontynentalnym protestantyzmem ${ }^{14}$. Równocześnie przeprowadzono akcję pacyfikacji opornych, zarówno katolików, jak i kalwinistów, która jednak w odniesieniu do tych ostatnich przyniosła efekt odwrotny do zamierzonego, konsolidując ruch i skłaniając go do podjęcia politycznej i intelektualnej walki z Kościołem episkopalnym. Najważniejszymi postaciami kalwińskiego oporu byli Thomas Cartwright, profesor teologii w Lady Margaret College, oraz Walter Travers, będący autorami teologicznie uzasadnionego programu zmian konstytucyjnych o rewolucyjnym charakterze. Ich postulaty, najogólniej rzecz ujmując, sprowadzały się do oczyszczenia (purtification) Kościoła anglikańskiego z wpływów papizmu, który uważali za wcielenie Antychrysta i Bestii, oraz przeprowadzenia reformacji do końca ${ }^{15}$. Dlatego metody polityczne, choć na krótką metę skuteczne, musiały być jedynie wstępem do poważnej, teologicznej debaty z purytanami. To w jej toku miało się wyłonić koherentne i przekonujące teoretyczne uzasadnienie nowego porządku religijnego oraz podstawa funkcjonującej w tych warunkach monarchii. I choć wyzwanie purytanom rzucali prominentni hierarchowie anglikańscy, to ich pokonanie i narodziny samej anglikańskiej teologii wiążą się z działalnością Richarda Hookera, duchownego anglikańskiego i najwybitniejszego teologa okresu elżbietańskiego ${ }^{16}$.

Jego słynne niedokończone Of the Laws of Ecclesiastical Polity stały się jednak nie tylko najważniejszą apologią Kościoła episkopalnego, lecz również szeroko komentowanym traktatem prawnym i politycznym obecnym w dyskursie jeszcze na długo po śmierci autora w dzień Wszystkich Świętych roku $1600^{17}$. Jego bezpośrednim celem, wyrażonym na początku traktatu, jest obrona konstytucji i praktyk Kościoła elżbietańskiego przed radykałami ${ }^{18}$ oraz przedstawienie wyważonej reformowanej katolickiej teologii sformułowanej w XVI-wiecznej Anglii przez Thomasa Caranmera i Johna Jewela, mającej źródło w Piśmie, tradycji i rozumie ${ }^{19}$. To wielkie dzieło jest jednak nie tylko

14 A. Nichols, The Panther and the Hind. A Theological History of Anglicanism, T. \& T. Clark, Edinburgh 1993, s. 37-52; przeciwnie patrz: N. Atkinson, Richard Hooker and the Authority of Scripture, Tradition, and Reason. Reformed Theologian of the Church of England?, Paternoster Press, Carlisle 1997.

15 A.F.C. Pearson, Church and the State. Political Aspects of Sixteenth Century Puritanism, The University Press, Cambridge 1928, s. 37-38; J.R. Beeke, R.J Pederson., Meet the Puritans, Reformation Heritage Books, Grand Rapids 2006, s. xv; E.S. Morgan, Visible Saints. The History of a Puritan Idea, Cornell University Press, Ithaca 1965, s. 1-32.

16 Richard Hooker urodził się w 1554 r. w Heavitree w hrabstwie Devon. Początkowo nauki pobierał w Exeter Grammar School, a następstwie w wyniku protekcji swego wuja wstąpił do Corpus Christi College w Oxfordzie. W 1579 r. przyjął święcenia kapłańskie z rąk ówczesnego biskupa Londynu Edwina Sandysa, który uczynił go nauczycielem swego syna. W tym czasie Hooker był również wychowawcą siostrzeńca arcybiskupa Thomasa Cranmera. W 1584 r. otrzymał stanowisko rektora St. Mary’s Drayton Beauchamop, choć prawdopodobnie nigdy go nie objął. W roku następnym został bowiem mianowany rektorem Temple Church w Londynie. Na ten okres datuje się początek jego polemiki z Traversem i pracy nad The Laws of Ecclesiastical Polity. Ostatnie lata życia spędził w parafiach St. Mary the Virgin w Bishopsbourne i St. John the Baptist Barham w Kencie. Zmarł 3 listopada 1600 r. i został pochowany w prezbiterium kościoła w Bishopsbouirne.

17 Księgi I, II, III i IV ukazały się w 1593 r., księga V w 1597, VI i VIII w 1548, VII zaś dopiero w 1662 P. Lake, Anglicans and Puritans? Presbyterianism and English Conformist Thought from Whitgift to Hooker, Unwin Hyman, London Boston 1988, s. 38-39.

18 P. Collinson, Hooker and the Elizabethan Establishment [w:] Richard Hooker and the Construction of Christian Community, red. A.S. McGrade, Medieval \& Renaissance \& Studies, Tempe 1977, s. 171.

19 J. Booty, Hooker and Anglicanism [w:] Studies in Richard Hooker: Essays Preliminary to an Edition of His Works, red. W.S. Hill, Press of Case Western Reserve University, Cleveland 1972, s. 207-210. 
apoteozą monarchii mieszanej, Kościoła państwowego i polemiką z oponentami ${ }^{20}$; jest także poszukiwaniem przez głęboko wierzącego chrześcijanina i teologa części, z których utkana jest tkanina stworzenia, poszukiwaniem fundamentów kosmosu z wielką precyzją zaprojektowanego przez Stwórcę. Szuka ich więc Hooker nie tylko, jak jego przeciwnicy, w objawieniu, lecz również w odziedziczonej mądrości przeszłych pokoleń, naturze człowieka i dziele stworzenia. Of Laws jest zatem właściwie wielkim wykładem Hookerowskiej teorii i filozofii prawa - rzecz niebywale oryginalna, jeśli chodzi o ówczesną debatę teologiczną. Autor wie jednak, że tylko podważając w sposób przekonujący normatywną purytańską interpretację Pisma, jest w stanie dać solidne podstawy całemu systemowi politycznemu. Dlatego celem artykułu jest rekonstrukcja Hookerowskiej koncepcji prawa i wynikającej zeń genezy porządku politycznego. Na początku zatem przedstawię osadzoną głęboko w tradycji tomistycznej, choć oryginalną, teorię genezy i hierarchii prawa. Przejdę następnie do wyprowadzonej zeń wizji porządku społecznego i politycznego, której ostatecznym celem polemicznym była dla Hookera intelektualna kompromitacja argumentu purytańskiego, a przez to teologiczna i racjonalna afirmacja koncepcji monarchii prawa oraz przede wszystkim legitymizacja porządku monarchii elżbietańskiej²1.

Już na samym początku Of Laws of Ecclesiastical Polity Hooker dokonuje konstytutywnej dla całej swej teologii politycznej analizy porządków normatywnych, która - jak się przekonamy - jest głęboko osadzona w rozważaniach scholastycznych myślicieli średniowiecza, przede wszystkim zaś myśli Akwinaty (przez co purytanie oskarżali go o „promowanie rzymskiej doktryny” i ,scholastycznego błędu”) oraz klasycznej tradycji Arystotelejskiej22, które miały w Anglii długą tradycję i zachowały część

20 B. Vickers, Introduction 2 [w:] Of the Laws of Ecclesiastical Polity, Sidgwick \& Jackson, London 1973, s. 41-59; R. Almasy, The Purpose of Richard Hooker 's Polemic, ,Journal of the History of Ideas” 1978, vol. 39 , s. 251-270.

21 Teologia polityczna Hookera nie doczekała się do tej pory w języku polskim gruntownego opracowania. Najobszerniej problematyką tą zajmuje się B. Szlachta w jednym z rozdziałów swej monografii poświęconej debacie politycznej doby Tudorów (B. Szlachta, Monarchia prawa? Angielska myśl polityczna doby Tudorów, Księgarnia Akademicka, Kraków 2007). Wspomina też o nim P. Musiewicz w swej krótkiej analizie brytyjskiej tradycji prekonserwatywnej (Wartość zwyczaju i tradycji w koncepcjach brytyjskich prekonserwatywnych i konserwatywnych myślicieli politycznych, „Annales UMCS Sectio K: Politologia”, vol. XVIII, 1/2011, s. 115-128). Oczywiście inaczej kwestia ta przedstawia się w literaturze anglosaskiej, choć, co zadziwiające, trudno uznać Hookera za myśliciela cieszącego się wśród uczonych popularnością. Zmianę tego stanu rzeczy przyniosło ostatnie kilkadziesiąt lat, przede wszystkim za sprawą wznowienia w 1989 r. po długiej przerwie opus magnum Hookera oraz monografii W.J.T.Kirby'ego (Richard Hooker, Reformer and Platonist, Asgate, Aldershot 2005; Richard Hooker's Doctrine of the Royal Supremacy, E.J.Brill, LeidenNew York 1990).

22 L.W. Gibbs, Introduction, Book I [w:] The Works of Richard Hooker, vol. VI, part. I, Of the Laws of Ecclesiastical Polity I-IV, Medieval \& Renaissance Texts \& Studies, Binghamton, New York 1993, s. 103. Przy okazji warto pochylić się na chwilę nad problemem prawa rzymskiego w Anglii okresu Tudorów. Należy jednak badać go w kilku płaszczyznach. Po pierwsze, z uwagi na inną tradycję prawną, nigdy nie mieliśmy do 
wpływów ${ }^{23}$. W przeciwieństwie jednak do swoich średniowiecznych poprzedników, dla których analiza prawa miała charakter wtórny, Hooker czyni z niej fundament swojego systemu. To bowiem, jak twierdzi, z błędnego rozumienia jego natury i pomieszania różnych jego porządków wynikają błędy dotyczące problematyki władzy i ustroju Kościoła. Celem jego przedsięwzięcia jest zatem wykazanie błędności purytańskiej perspektywy, w której wszystkie ludzkie działania są poddane teologicznej ocenie za pomocą prawa Bożego ujawnionego w Piśmie Świętym. Nie przeczy, że jest ono najwyższym prawem w kwestii zbawienia, lecz pragnie równocześnie dowieść, iż prawo Boskie nie jest jedynym prawem, którym Stwórca w swej dobroci obdarzył swe stworzenia. Jego przedmiotem nie jest więc „,wiedza naturalna”, lecz „wiedza nadprzyrodzona"; nie pokazuje, w jaki sposób zbudować dom czy zaorać pole. Negując stanowisko Cartwrighta, z którym otwarcie polemizuje, stwierdza, że ani sama Biblia, ani Ojcowie Kościoła, ani żaden szanowany angielski teolog nie ogranicza znajomości chrześcijańskich praw Bożych do objawienia. Cechą bowiem rodzaju ludzkiego jest funkcjonowanie na kilku poziomach wielkiego systemu normatywnego zgodnie z rozmaitymi aspektami ludzkiej natury i działalności. Oczywiste jest bowiem, że

ponieważ ludzkie działania są rozmaitych rodzajów, zatem prawa rozmaitych rodzajów również muszą zostać rozróżnione. Jest w ludzkich działaniach - twierdzi dalej Hooker - coś naturalnego, coś racjonalnego, coś nadprzyrodzonego, coś politycznego, w końcu coś związanego z Kościołem, które jeśli mierzone są nie przez właściwe im prawo, w sytuacji gdy rzeczy te są tak od siebie różne, wprowadzą zamieszanie do naszego ich zrozumienia i osądu ${ }^{24}$.

czynienia z tak daleko idącą jego recepcją jak na kontynencie. Awersja ta pogłębiła się jeszcze, z oczywistych przyczyn, wraz z Aktem Supremacji, było ono bowiem dla wyspiarzy przejawem papizmu, którego wszelkie elementy starali się wykorzenić, mimo że niewątpliwie funkcjonowało ono $\mathrm{w}$ orzecznictwie przez setki lat (patrz: Ł. Korporowicz, Prawo rzymskie w orzecznictwie Izby Lordów w latach 1876-2009, Wydawnictwo UŁ, Łódź 2016). Choć w literaturze można odnaleźć stanowiska, iż czasy Tudorów stanowiły największy rozkwit prawa rzymskiego $\mathrm{w}$ angielskim porządku prawnym, to trzeba równocześnie zaznaczyć, że oznaczało to rozwój sądownictwa nienależącego do sfery common law, w którym wykorzystywano procedurę rzymsko-kanoniczną (np. sądy kościelne czy sąd admiralicji). Faktycznie, zdaniem J.H. Bakera, a wcześniej F.W. Maitlanda, panowanie Tudorów było tym okresem w dziejach prawa angielskiego, gdzie rzymska tradycja prawna mogła poważnie zagrozić funkcjonowaniu common law. Po drugie, pod żadnym pozorem nie należy jednak łączyć tego z próbą uzasadnienia władzy monarchów w tym okresie. Także utworzenie około 1540 r. przez Henryka VIII królewskich katedr prawa rzymskiego w Oxfordzie i w Cambridge nie może być traktowane jako przykład powyższego założenia. Katedry te stanowiły bowiem jedynie odpowiedź na zniesienie, przynajmniej teoretyczne, wykładów prawa kanonicznego w następstwie reformacji. Zatem podczas panowania Henryka VIII, Elżbiety I i dwóch pierwszych Stuartów oskarżenia o romanizację prawa (Sąd Izby Gwiaździstej, Wysoka Komisja) często padały ze strony parlamentarnej opozycji widzącej w nich instrument budowania monarchii absolutnej wzorem rozwiązań kontynentalnych. Mimo tego zwolennicy tych rozwiązań (w praktyce teoretycy boskiego prawa królów, vide Saravia czy Filmer) nigdy do argumentacji opartej na prawie rzymskim nie sięgali, zadowalając się wywodzeniem absolutnej władzy monarchów z argumentu biblijnego bądź historycznego (konstytucyjnego). Prawo rzymskie nie było więc w owym czasie traktowane jako argument legitymizujący czy delegitymizujący władzę w żadnej z dominujących, choć często przeciwstawnych koncepcji.

23 P. White, Predestination, Policy and Polemic. Conflict and Consensus in the English Church from the Reformation to the Civil War, Cambridge University Press, Cambridge-New York-Port Chester-MelbourneSydney 1992, s. 126.

24 Of Laws of Ecclesiastical Polity I, 16 [w:] The Works of Richard Hooker, Clarendon Press, Oxford 1820, s. 286 (jeśli nie wskazano inaczej, wszystkie cytaty z Of Laws pochodzą z niniejszego wydania dzieł Hookera).

Artykuły - Articles 
Wbrew stanowisku Kalwina, akcentującego suwerenność Boga ${ }^{25}$, Hooker dowodzi, że Prawo „wyznacza każdej rzeczy jej rodzaj, miarkuje siłę i władzę, wyznacza formę i miarę działania" ${ }^{26}$. Jest wiec odpowiednim z natury wzorcem postępowania, zgodnie z którym wszystkie rzeczy zmierzają do swej doskonałości. Odrzuca zatem nominalizm i formalizm kładące nacisk na Bożą wolę ${ }^{27}$, miast tego skłaniając się ku Bożemu rozumowi. To on bowiem zawsze kieruje Jego wolą, stąd wszelkie prawo ma ostatecznie źródło w woli, która jest racjonalna. Jego koncepcja prawa jest przez to w istocie próbą rehabilitacji rozumu, podeptanego i zmarginalizowanego przez purytanów ${ }^{28}$, którzy „nigdy nie używają rozumu tak chętnie, jak go hańbią" ${ }^{29}$. Wbrew bowiem ojcom reformacji, którzy nigdy nie zdezawuowali rozumu autonomicznego w tak radykalny sposób, purytanie odmówili niemal całkowicie prawomocności jego roszczeniom, na rzecz nieograniczonego i czasem posuniętego do absurdu autorytetu Pisma Świętego ${ }^{30}$ - „rygorystycznej i systematycznej bibliolatrii” ${ }^{31}$. Dlatego, jak pisał Carwright, ,słowo Boga określiło kierunek wszystkich rzeczy dotyczących Kościoła, powiadam wam, tak samo jak wszystkich rzeczy, które mogą stać się częściami życia człowieka"32. Jest zatem Biblia jedynym przewodnikiem we wszystkich działaniach - publicznych, prywatnych i politycznych. Musi więc Hooker stworzyć koncepcję prawa opartą na zupełnie innych założeniach i w tym celu sięga do tradycji scholastycznej, przede wszystkim zaś do Akwinaty.

Na początku swego wywodu Hooker pisze więc o „prawie wiecznym” rządzącym całym Boskim stworzeniem, będącym zespołem niezmiennych i racjonalnych norm, które „sam Bóg ustanowił jako wieczne dla wszystkich swoich dziel”33 i poprzez które ujawnia swą mądrość i dobroć ${ }^{34}$. To porządek, który „przed początkiem czasu Bóg ustanowił w sobie, dla siebie i by wszystko czynić"35. Stoi ono na szczycie hierarchii praw, będąc „najwyższym źródłem i fontanną"36, z którego wypływają wszystkie inne prawa. W jego ramach Hooker dokonuje jednak istotnej dystynkcji, której próżno szukać u Augustyna czy Akwinaty, pisze bowiem o „pierwszym prawie wiecznym”, kierującym działaniami samego Boga, i „drugim”, któremu podporządkowane jest wszelkie stworzenie. Wiąże się to w koncepcji Hookera z rozdzieleniem „wewnętrznej” i „zewnętrznej” aktywności Stwórcy ${ }^{37}$. To zastosowanie pojęcia prawa nie tylko do zewnętrznej, ale i wewnętrznej

25 J. Calvin, Institutes of the Christian Religion, I, XVI, 7, trans. F.L. Battles, Westminster John Knox Press, Louisville 1960, vol. I, s. 206.

26 I, 2, s. 199.

27 A. Passerin d'Entrèves, Natural Law. An Introduction to Legal Philosophy, Hutchinson and Co. Ltd., London 1951, s. 68.

28 J.W. Allen, A History of Political Thought in the Sixteenth Century, Methuen \& Co. Ltd, London 1941, s. 189.

29 III, 8, s. 377.

30 L. Strauss, J. Cropsey, Historia filozofii politycznej, Fronda, Fundacja Augusta hr. Cieszkowskiego, Warszawa 2010, s. 359.

31 B.M. Berry, Process of Speech. Puritan Religious Writing \& Paradise Lost, Johns Hopkins University Press, Baltimore 1976, s. 146.

32 Cyt. za: A.S. Rosenthal, Crown under Law, Richard Hooker, John Locke, and the Ascent of Modern Constitutionalism, Lexington Books, Lanham 2008, s. 15.

33 I, 3, s. 204.

34 B. Szlachta, Monarchia prawa?..., s. 601.

35 I, 2, s. 198.

36 I, 1, s. 197.

37 T. Kirby, Richard Hooker, Reformer and Platonist..., s. 46-47. 
aktywności Boga możliwe jest właśnie dzięki nowatorskiej jego definicji. Ta pierwsza sprowadza się do naturalnej i koniecznej aktywności boskiego bytu oraz jego woluntarystycznych działań. Są one immanentnie związane z boską creatio i równocześnie podporządkowane prawu, które „Bóg ustanowił sam dla siebie i stąd obejmuje wszystkie rzeczy, których jest przyczyną i autorem" ${ }^{\text {"38 }}$. Bóg zatem jest prawem dla samego siebie, jego prawo i jego czyny są jednym i tym samym. W jedności swej substancji jest zarówno twórcą, jak i prawem, zgodnie z którym tworzy swe dzieła. Tak jak Trójca jest jednością, tak Bóg z samej swej natury i zasady niepodzielności jest twórcą siebie, schematem tworzenia i rzeczywistym aktem tworzenia. W przypadku wszystkich innych bytów zaś momenty te są ontologicznie rozdzielone ${ }^{39}$. „Zewnętrzna” aktywność Boga zakłada zaś gubernatio, czyli rządzenie stworzonym wcześniej bytem. Stąd cały kosmos poddany jest ostatecznie rozumnym regułom mającym Boską proweniencję $e^{40}$. Drugi rodzaj prawa wiecznego jest zatem zbiorem zasad kierujących całym boskim stworzeniem, regułami respektowanymi nieświadomie przez wszystkie byty, regułami, wedle których funkcjonują świat materii nieożywionej i istoty żyjące. Każda przeto rzecz i istota podlegają właściwym dla nich prawom, odpowiednim dla ich natury, mającym źródło w Bożej mądrości i miłości. Prawa te zaszczepione są przez Stwórcę w jego stworzeniu, „ustanowione, by były szanowane przez wszystkie jego stworzenia" ${ }^{41}$, i zawarte są w naturalnym porządku rzeczy Boskiego uniwersum.

Te niezmienne prawa rządzące kosmosem tworzą pierwszą podkategorię prawa wiecznego, którą wyróżnia Hooker - prawo natury (Nature’s law) mające charakter nieintelektualny i niewoluntarystyczny. Wbrew stanowisku Akwinaty, który prawo natury postrzega jako partycypację istot rozumnych w prawie wiecznym, Hooker określa je jako reguły, których jego adresaci przestrzegają nieświadomie. W ten sposób zrównuje je z prawami natury fizycznej i fizyczną regularnością wszechświata. Obok prawa natury Hooker wymienia dalej prawo niebieskie (celestial law), „które Aniołowie wyraźnie dostrzegają bez żadnego odstępstwa”, oraz prawo rozumu (law of Reason), „wiążące istoty rozumne na tym świecie, które dzięki rozumowi mogą wyraźnie dostrzec, że je obowiązuje"42. Szczególnie to ostatnie, które czasem nazywa prawem naturalnym, jest przedmiotem zainteresowania Hookera. Ludzie bowiem, tak jak inne istoty rozumne, aktywnie poszukują najwyższego dobra, jakim jest Bóg ${ }^{43}$. To dzięki rozumowi potrafią więc odróżnić dobro od zła, prawdę od fałszu i szukać celu wykraczającego poza ich fizyczną naturę, którą dzielą ze zwierzętami ${ }^{44}$. Zatem rozum i objawienie nie pozostają w konflikcie, lecz tworzą harmonijną całość, a Pismo nie niweczy natury, lecz ją udo-

38 I, 2, s. 200.

39 T. Kirby, Richard Hooker, Reformer and Platonist..., s. 48.

40 I, 2, s. 197.

41 I, 3, s. 204.

42 I, 3, s. 205.

43 T. Kirby, Richard Hooker's Theory of Natural Law in the Context of Reformation Theology, „The Sixteenth Century Journal" 1999, vol. 30, no. 3 (Autumn), s. 688-690.

44 A.P. Monahan, Consent, Coercion and Limit. The Medieval Origins of Parliamentary Democracy, McGill-Queen's University Press, Kingston 1987 [w:] Richard Hooker and the Construction ..., red. A.S. McGrade, s. 208. 
skonala ${ }^{45}$. Wspomaga rozum, by stał się efektywnym narzędziem odkrywania prawdy ${ }^{46}$ i mógł interpretować właściwie objawienie ${ }^{47}$.

Dlatego też racjonalne prawo - pisze - które ludzie zwykle nazywają prawem naturalnym, oznacza prawo, którym ludzka natura rozumna jest powszechnie związana, które $\mathrm{z}$ tego powodu jest słusznie nazywane również prawem rozumu. To prawo, zapewniam, objęło wszystkie te rzeczy, które ludzie dzięki światłu ich naturalnego rozumienia znają, lub przynajmniej mogą znać, określa jako stosowne lub niestosowne, cnotliwe lub występne, dobre lub złe w tym, co czynią ${ }^{48}$.

Jest ono powszechne i umożliwia nawet niechrześcijanom poznanie woli Boga, dla chrześcijan jest jednak szczególnie ważne, ponieważ Pismo nie wystarczy jako jedyny przewodnik ku zbawieniu, lecz zakłada znajomość prawa naturalnego. Przeszkodą w jego poznaniu może być jednak grzech pierworodny, przez który człowiek nie może w pełni posługiwać się rozumem, opierając się prawidłowemu wskazaniu tego, co dobre. Innym razem utrudniać to mogą lenistwo, ignorancja, lecz generalne spojrzenie Hookera na ludzką naturę jest optymistyczne w tym znaczeniu, że wierzy, iż potrafi ona dostrzec różnicę pomiędzy prawdą i kłamstwem, cnotą i występkiem, iż potrafi okiełznać swe żądze i dokonać zgodnych z rozumem moralnych wyborów. Choć zatem dzieli z oponentami przekonanie o deprawacji ludzkiej natury, to nie jest ona u niego tak zupełna. Nie może być inaczej, wtedy bowiem jego rozważania na temat prawa rozumu nie miałyby żadnego sensu. Ludzki rozum ma bowiem naturalną skłonność i zdolność do odkrywania uniwersalnych praw ${ }^{49}$. Odrzuca jednak Hooker średniowieczny i stoicki punkt widzenia, zgodnie z którym ich znajomość była powszechna w rodzaju ludzkim, od kiedy Bóg zaszczepił jego treść w sercach i umysłach ludzi ${ }^{50}$. Zamiast tego twierdzi, że zdolność ta rozwija się u ludzi stopniowo poprzez kontemplację Bożego dzieła ${ }^{51}$. Tak samo bowiem, jak cała przyroda związana jest prawem, tak istnieją reguły odnoszące się do człowieka, a ich treścią są rozpoznawane przez ludzki rozum, nawet bez pomocy Stwórcy, naturalne obowiązki.

Prawa Naturalne mają cechy - pisze - które pozwalają je rozpoznać. [...] Wszystkie działania Natury są celowe, piękne, bez nadmiaru i niedoskonałości, ponieważ dzieją się zgodnie z tym, czego naucza Prawo Rozumu. Po drugie, Prawa te są rozpoznawalne przez Rozum, bez pomocy nadnaturalnego i boskiego Objawienia ${ }^{52}$.

45 W.D. Neelands, Hooker on Scripture, Reason, and ,Tradition” [w:] Richard Hooker and the Construction..., red. A.S. McGrade, s. 76.

46 W.P. Haugaard, The Scriptural Hermeneutics of Richard Hooker. Historical Contextualization and Teleology, [w:] This Sacred History. Anglican Reflections for John Booty, ed. D.S. Armentrout, Cowley Publications, Cambridge 1990, s. 161-174.

47 S.L. Bethell, The Cultural Revolution of the Seventeenth Century, Dennis Dobson, London 1963, s. 22.

48 I, 8, s. 234.

49 I, 8, s. 224.

50 R.K. Faulkner, Richard Hooker and the Politics of a Christian England, University of California Press, Berkeley-London 1981, s. 85-86.

${ }_{51}$ L.W. Gibbs, Introduction, Book I [w:] The Works of Richard Hooker, vol. VI, part. I, s. 106; W.D. Neelands, Hooker on Scripture, Reason, and „,Tradition” [w:] Richard Hooker and the Construction ..., red. A.S. McGrade, s. 79.

52 I, 8, s. 233. 
Zatem realizując naturalne, przyrodzone skłonności nadane ludziom przez Boga, mimowolnie realizujemy reguły prawa naturalnego. Wskazuje przy tym dwie naturalne drogi (natural ways) poznania reguł danych człowiekowi przez Boga. Pierwszą, trudniejszą i rzadko stosowaną, jest powrót do zasad pierwszych i wydedukowanie $\mathrm{z}$ ich treści, jakie są przyczyny dobra, drugi sposób polega natomiast na doświadczalnym odkryciu znaków związanych z dobrocią, z których „,powszechna zgoda ludzi jest najdoskonalszym i najsilniejszym jego rodzajem”, ponieważ ,powszechny i wieczny głos ludzi jest niczym wyrok Boga samego" ${ }^{53}$. Ta powszechna zgoda rodzaju ludzkiego oparta jest na oczywistej intuicji będącej podstawą propozycji rozpatrzonej i zaakceptowanej przez poszczególnych ludzi.

W dalszej kolejności Hooker przechodzi do prawa Boskiego (Divine law), „które poznawane jest nie inaczej, jak tylko przez Boskie objawienie" ${ }^{4}$. Jest ono u Hookera darem łaski, przez który Stwórca wkracza w sferę prawa rozumu poprzez jego udoskonalenie. Broni więc rozumu jako właściwego narzędzia wiedzy, lecz nie jako narzędzia zdobycia wiedzy ostatecznej, ponieważ Bóg wyposażył człowieka w rozum, który nie jest jednak w stanie poznać wszystkich tajemnic zbawienia ${ }^{55}$. Tak jak Akwinata, Hooker twierdzi, że Bóg dał człowiekowi dwa światła, za pomocą których odkrywa on prawo. Przez nadnaturalne światło wiary człowiek jest zdolny dostrzec i zaakceptować prawo objawione w Piśmie, a dzięki naturalnemu światłu rozumu poznaje prawo naturalne ${ }^{56}$. W Arystotelejsko-Tomistycznym duchu wyjaśnia więc, że Bóg poprzez objawienie komunikuje swemu stworzeniu prawa, których człowiek nigdy nie byłby w stanie sam odkryć $^{57}$. Wszystkie istoty pragną osiągnąć doskonałość właściwą ich naturze, odróżniając przy tym pomiędzy tymi dobrami, które są pożądane jako środki dla osiągnięcia tego, co jest pożądane same w sobie. Hooker stwierdza za Tomaszem, że Bóg jako jedyne nieskończone i doskonałe dobro jest ostatecznym celem pożądanym przez istoty ludzkie i tylko on jest jedynym źródłem szczęścia. Stąd doskonałość, jakiej pragną istoty ludzkie, może być osiągnięta poza światem doczesnym. Tylko tam istnieje nieskończone dobro, które może zaspokoić bezgraniczną ludzką tęsknotę, która na ziemi nie znajdzie spełnienia. Hooker twierdzi, że sam rozum, skażony grzechem pierworodnym, może, poza nakazem spełniania dobrych uczynków, nie wskazywać środków wystarczających do osiągnięcia tego najważniejszego celu. Stąd wniosek, że albo Boga nie ma, co jest oczywistym absurdem, albo sam Stwórca musi wskazać ludziom drogę osiągnięcia wiecznego szczęścia. I rzeczywiście uczynił tak poprzez wskazanie nie tylko najważniejszych zasad prawa rozumu i ich praktycznych aplikacji, lecz również mistycznych i nadnaturalnych dróg osiągniecia zbawienia duszy poprzez wypełnianie nakazów wiary, nadziei i miłości, które można znaleźć tylko w Piśmie Świętym. Ma jednak ono u Hookera oczywiście status szczególny, jako bezpośredni głos Boga kierowany do człowieka, wyprzedza zatem prawo rozumu i prawo ludzkie jako potencjalnie dotknięte ułomnością ludzkiego rozumu. „Jeśli - pisze więc - wiele bodźców obok Pisma Świętego może

53 I, 8, s. 226.

54 I, 3, s. 205.

55 J. R. Parris, Hooker's Doctrine of the Eucharist, „Scottish Journal of Theology” 1963, vol. 16, s. 163;

J. Hunt, Religious Thought in England in the Nineteenth Century, Gibbings \& Co., London 1896, s. 60.

56 A.S. Rosenthal, Crown under Law..., s. 59.

57 L.W. Gibbs, Introduction, Book I [w:] The Works of Richard Hooker, vol. VI, part. I, s. 117. 
mnie prowadzić do wniosków, które są mu przeciwne, wtedy wszystkie one muszą ustąpić i są bez wartości, jakkolwiek silnie i skutecznie mnie przekonują"58.

W końcu w swych rozważaniach Hooker dochodzi do prawa ludzkiego (Human law), wywiedzionego z prawa rozumu, i korzyści, jakie z sobą niesie. $\mathrm{W}$ ten sposób dokonuje jego wstępnej klasyfikacji, dzieląc je na prawo ludzkie mieszane (mixedly human) oraz prawo wyłącznie ludzkie (merely human). Pierwsze z nich ustanawia obowiązki, do których człowiek jest zobowiązany na mocy prawa Bożego i prawa rozumu, a zatem stanowi partycypację w prawie natury. Wyjaśniają one, dlaczego winniśmy posłuch prawu Bożemu i prawu naturalnemu lub wiążą z wynikającymi zeń obowiązkami nagrody i kary. Inaczej rzecz przedstawia się w przypadku drugiej odmiany praw ludzkich, które ustanawiane są jedynie z uwagi na wynikający z nich dla społeczeństwa pożytek i mają charakter czysto konwencjonalny. Tworzą one obowiązki nieopisane wcześniej w kategoriach prawa Bożego i prawa Rozumu. Prawo ludzkie, będące w kontekście celu traktatu szczególnym przedmiotem jego zainteresowania, jest przez Hookera wyraźnie oddzielone od prawa Rozumu na trzech płaszczyznach. Po pierwsze, ma ono charakter przymusowy, towarzyszy mu bowiem sankcja państwowa; po drugie, ma tylko lokalny zasięg odnoszący się do konkretnej wspólnoty politycznej (oprócz oczywiście prawa narodów), po trzecie w końcu, ma ono, i jest to cecha istotna dla dalszych rozważań, charakter zmienny w czasie ${ }^{59}$. Historyczny ogląd dziejów ludzkości wskazuje bowiem, że różne narody $\mathrm{w}$ różnych czasach $\mathrm{w}$ zależności od okoliczności rządzą się różnym prawem. Wbrew purytanom, którzy patrzyli na system prawny statycznie i holistycznie, Hooker odnosił te cechy jedynie do prawa Bożego określającego drogę ku zbawieniu oraz prawu natury, resztę pozostawiając ludzkiemu wyborowi, rozumowi i doświadczeniu $^{60}$. Jako że prawa ludzkie są wpisane w cały system normatywny, istotne znaczenie ma ich relacja do praw stojących wyżej w hierarchii. „Prawa Ludzkie są kryterium w odniesieniu do ludzi, których działaniami muszą kierować, lecz kryterium to musi mieć również wyższe zasady, którymi są Prawo Boże i Prawo Natury" - pisze Hooker. „Zatem Prawa Ludzkie - i w tym miejscu Hooker odwołuje się do Akwinaty - muszą być tworzone zgodnie z ogólnym Prawami Natury i bez sprzeczności z jakimś bezdyskusyjnym prawem zawartym w Piśmie, inaczej czynią one zło"61.

\section{II}

Mimo że w hierarchicznej strukturze prawa prawo ludzkie znajduje się najniżej, to wydaje się, że ma dla Hookera największe znaczenie w kontekście określonych relacji społecznych, których uzasadnienia poszukuje. Jego istnienie bowiem jest immanentnie

58 II, 5, s. 317.

59 W.D.J. Cargill Thompson, The Philosopher of the "Politic Society". Richard Hooker as a Political Thinker [w:] Studies in Richard Hooker..., s. 33.

60 S.L. Collins, From Divine Cosmos to Sovereign State. An Intellectual History of the Idea of Order in Renaissance England, Oxford University Press, New York 1989, s. 91 i n.

61 III, 9, s. 394. 
związane z istnieniem władzy politycznej, dlatego wywód musi się rozpocząć od wskazania przyczyn konieczności jej istnienia. Dla Hookera

są dwa powody podtrzymujące społeczeństwa (publique societies), pierwszym jest naturalna skłonność, zgodnie z którą wszyscy ludzie pragną życia gromadnego i zjednoczenia, drugim nakaz bezpośrednio lub milcząco uzgodniony dotyczący sposobu ich zjednoczenia we wspólnym życiu ${ }^{62}$.

Nie jest zatem w tym względzie oryginalny, sięga bowiem, po pierwsze, za pośrednictwem Tomasza, do argumentu Arstotelesa, wedle którego człowiek jest z samej swej natury zwierzęciem społecznym. To odwołanie do poganina ma dla Hookera ten istotny walor, że pozwala na racjonalne wyjaśnienie genezy społeczeństwa politycznego bez odwołania się do objawiania czy też chrześcijańskiej moralności. Powołanie do życia we wspólnocie jest elementem prawa natury, któremu ludzie podporządkowują się bezrefleksyjnie i niewoluntarystycznie, niezależnie od poglądów na religię i Boga. To ono bowiem zaspokaja podstawowe ludzkie potrzeby, powstając jako konieczna konsekwencja naturalnej ludzkiej konstytucji, a nie twór konwencjonalny ${ }^{63}$.

Zważywszy na to - przekonuje zatem - że nie jesteśmy sami dostatecznie wyposażeni w kompletny zapas rzeczy potrzebnych do życia takiego, do jakiego skłania nas nasza natura, życia godnego człowieka, dlatego, by zniwelować te wady i niedoskonałości, które są właściwe pojedynczemu człowiekowi, z natury jesteśmy zachęcani, by zwracać się ku wspólnocie i towarzystwu innych. Taka była przyczyna połączenia się ludzi w pierwsze społeczeństwa polityczne ${ }^{64}$.

Naturalny instynkt społeczny zaszczepiony człowiekowi przez Boga każe mu zatem dokonać społecznego zjednoczenia. Skoro można określić moment, choćby rozłożony w czasie, powstania społeczeństwa, to musi istnieć też stan ,przed”. I choć Hooker nie posługuje się pojęciem stanu natury, to przyjęcie założenia, że wszyscy ludzie są w nim wolni, równi i niezależni, jest jedynym sposobem uzasadnienia jego pochodzenia bez odwołania się do bezpośredniej Bożej ingerencji. Pamiętać należy jednak, że Hooker nie myśli w kategoriach indywiduum, czyniąc podmiotem nie jednostkę, lecz wspólnotę, która jest dla niego jedyną realnością. Przedmiotem jego namysłu jest jedynie stan społeczeństwa naturalnego. W stanie takim obowiązują bezpośrednio reguły prawa natury, które „wiążą ludzi całkowicie, ponieważ są ludźmi, chociaż nie związali się w żadną wspólnotę i nie zawarli między sobą żadnego porozumienia, co czynić, a czego nie"65. Teoretycznie więc Hooker dopuszcza sytuację, w której społeczeństwo naturalne funkcjonuje bez władzy politycznej. Możliwość taka jednak została ostatecznie zniweczona przez grzech pierworodny, dlatego stan społeczeństwa naturalnego nie jest przedmiotem szerszej analizy Hookera. Po akcie Upadku bowiem rozpoznanie i przestrzeganie prawa natury nie jest, z uwagi na ludzką deprawację, powszechne i oczywiste.

Dlatego Hooker, wskazując sposób powstania społeczeństwa politycznego, odchodzi od optymizmu Arystotelesa i zwraca się ku chrześcijańskiej tradycji widzącej w nim remedium dla upadłej w skutek grzechu pierworodnego ludzkiej natury. Idąc śladem

62 I, 10 , s. 240

63 J.W. Gough, The Social Contract. A Critical Study of its Development, Clarendon Press, Oxford 1957 , s. 72.

64 I, 10, s. 240

65 I, 10, s. 240. 
Tomasza, stara się zatem pogodzić koncepcję społeczeństwa naturalnego z Augustyńską perspektywą (kontynuowaną przez Lutra i Kalwina), w której władza jest koniecznością wynikającą z Upadku ${ }^{66}$. Dlatego o ile społeczeństwo naturalne powstaje wskutek realizacji skłonności wpisanych w ludzką kondycję, o tyle nie może ono funkcjonować bez istnienia władzy moderującej egoistyczne zachowania wewnątrz wspólnoty. Grzech pierworodny uniemożliwiający zgodną i pokojową koegzystencję czyni więc instytucję rządu konieczną. Dla Hookera zatem w stanie społeczeństwa naturalnego, z uwagi na ludzką deprawację, wzrasta niesprawiedliwość i niepewność egzystencji, ponieważ nie ma władzy trzymającej ludzi w posłuchu. Sytuacja taka jest też sprzeczna z naturalnym ludzkim dążeniem do Boga, a tylko w społeczeństwie politycznym ludzie mają szanse być istotami prawdziwie moralnymi ${ }^{67}$. Brak rządu prowadzi do problemów z zarządzaniem sprawami publicznymi, rozstrzyganiem konfliktów, ochroną własności, dlatego jego sensem są „największe korzyści i bezpieczeństwo”, został ustanowiony jest, Bonum publicum, uniwersalne lub powszechne dobro"69. Stąd Hooker argumentuje:

By uniknąć wszystkich tych wzajemnych pretensji, szkód i krzywd, nie było innej drogi, by dojrzeli do porozumienia, by przez ustanowienie jakiegoś rodzaju publicznego rządu i podporządkowanie się temu, komu przyznali autorytet, by kierował i rządził, zdobyć pokój, spokój i szczęśliwe posiadanie majątku ${ }^{70}$.

Powstanie społeczeństwa politycznego ma zatem wedle Hookera miejsce poprzez bezpośrednie bądź dorozumiane porozumienie, którego treścią jest pierwotna zgoda przekazująca jakiemuś podmiotowi lub podmiotom władzę polityczną. Jej treścią jest wybór formy rządu i powstanie władzy politycznej, która swą legitymację czerpie właśnie ostatecznie $\mathrm{z}$ takiego właśnie porozumienia ${ }^{71}$. Nie ma tu przy tym żadnej sprzeczności z naturalistycznym postrzeganiem społeczeństwa, prawo natury bowiem nie determinuje ani nie określa formy społecznego zjednoczenia. Potrzebny jest do tego jakiś akt woli istoty rozumnej, która zaktualizuje i skonkretyzuje naturalne skłonności, a dla Hookera jedynym jego racjonalnym powodem jest właśnie porozumienie lub zgoda. Wzajemne waśnie i konflikty mogą być okiełznane jedynie przez władzę, na którą się zgodzili, ponieważ „,bez takiej zgody nie byłoby żadnego powodu, by jakiś człowiek był dla innych panem i sędzią"72. Co ważne, w tym miejscu Hooker wskazuje, że „Bóg, tworząc rodzaj ludzki, wyposażył go naturalnie w pełnię władzy, by kierował się do takich rodzajów

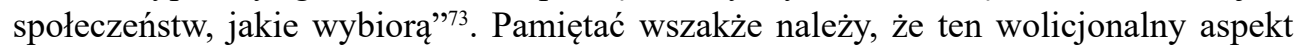
powołania rządu jest o wiele słabszy niż w późniejszych teoriach kontraktu, a powołanie rządu jest raczej wyrazem konieczności wynikającej z prawa rozumu ${ }^{74}$. Rząd nie jest jak u Hobbesa remedium na stan permanentnego chaosu, lecz niezbędnym narzędziem po-

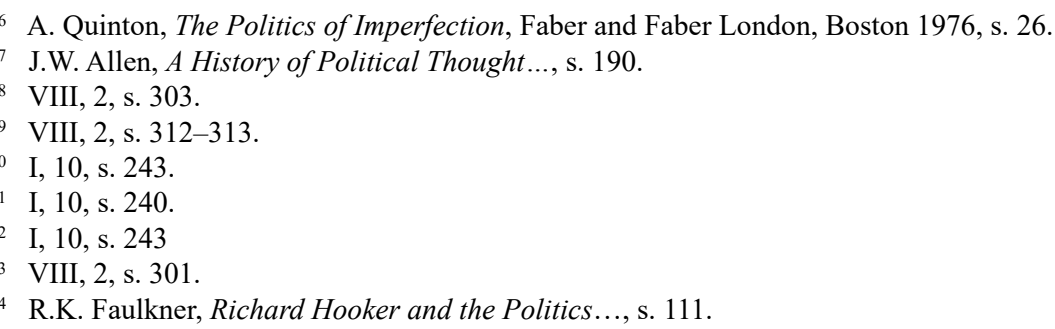


konania niedoskonałości wspólnego bytowania w społeczeństwie naturalnym i zapewnienia mu trwania. To on w końcu wprowadza ordo, umieszczając wszystkie elementy na właściwych im miejscach. Oczywiście musi posługiwać się siłą, ograniczać swobodę, lecz zamiast niej byłyby nieporządek i zamieszanie, a nie wspólne owocne życie.

Wszyscy skarżymy się - pisze Hooker - na niegodziwość naszych czasów, które nie są niesprawiedliwe, lecz po prostu złe, lecz porównajmy je z czasami, gdy nie było społeczeństwa obywatelskiego, z czasami, gdy nie było ustanowionego publicznego rządu, z czasami, gdy nie było więcej niż ośmiu prawych ludzi żyjących na powierzchni ziemi; i mamy oto dobry powód, by myśleć, że Bóg nadzwyczaj nam błogosławił i pozwolił doświadczać najszczęśliwszych dni ${ }^{75}$.

Sama natura dała przy tym wzorzec zorganizowania wspólnoty poprzez przykład rodzin, choć bowiem Hooker odrzuca patriarchalizm, który stanie się potem istotnym elementem doktryn uzasadniających boskie pochodzenie władzy monarszej, to nie może zignorować oczywistego faktu, że ojciec rodziny posiada naturalną władzę i autorytet. Monarchia jest zatem najbardziej oczywistym, lecz wcale nie koniecznym ustrojem. Hooker, analizując historyczne źródła władzy królewskiej, zauważa, że pochodzi ona z podboju, bezpośredniej boskiej nominacji lub wyboru rządzonych, a skupiając się na dwóch ostatnich, pisze:

Jedni, którzy w ten sposób otrzymują władzę, mają ją bezpośrednio od Boga na mocy Boskiego uprawnienia, inni przez prawo ludzkie stosownie do ludzkiego wyboru, kiedy jest Bóg, zezwala na wybór ich własnego rządcy. Niezależnie od sposobu, w który królowie i rządcy zostali ustanowieni, musimy uznać ich wybór zarówno za legalny, jak i zaaprobowany przez Boga, a ich samych za Boskich zastępców i uznać ich władzę ${ }^{76}$.

Choć wybór, w przeciwieństwie do Boskiej nominacji, jest aktem wyłącznie ludzkim, to dla Hookera jest akceptowalny przez Boga i posiada Boską sankcję, wywodzi się bowiem z prawa rozumu. Hooker idzie jednak dalej, akceptując prawowitość zasady dziedziczności władzy związaną immanentnie z tym sposobem jej otrzymania. Odrzuca więc tym samym kategorycznie żądania wyboru władcy, jakie można znaleźć w Vindiciae Contra Tyrannos i Franco-Galli Hotmana, nazywając ich zwolenników „siewcami rebelii" 77 . W dziedzicznej monarchii bowiem po śmierci władcy władza wracałaby każdorazowo do całej wspólnoty politycznej, czyniąc z niej jej pierwotnego dzierżyciela nie tylko w sensie filozoficznym, lecz i politycznym. Stąd już tylko krok od twierdzenia, że władca jest jej tylko czasowym i warunkowym dzierżycielem na określonych warunkach, których złamanie usprawiedliwia jego detronizację czy nawet tyranobójstwo. Sam Hooker doskonale zdawał sobie z tego sprawę, dlatego jedyny przypadek powrotu władzy do wspólnoty politycznej to bezdziedziczna śmierć władcy, lecz przezornie, uważając go za absolutny wyjątek, wątku tego nie eksploruje.

Wywody Hookera nie oznaczają więc, jak chcieliby jego purytańscy oponenci, że takie pochodzenie władzy umożliwia wspólnocie, która jest jej pierwotnym piastunem, dowolną, wolicjonalną zmianę formy władzy i podmiotów, które ją sprawują. Przeciwnie, Hooker stara się wykazać absurdalność i anarchiczne konotacje takich pretensji. Nie ma

75 I, 10, s. 243.

76 VIII, 3, s. 334.

77 VIII, 3, s. 304.

Artykuły - Articles 
zatem u niego pactum societatis, a pactum subiectionis występuje w formie szczątkowej. Przekazanie władzy na mocy pierwotnej zgody ma u Hookera charakter nieodwołalny, który realizuje się tylko jeden raz, poprzez pierwsze powołanie władzy, gdyż ,akt ustanowiony przez ogół społeczeństwa pięćset lat temu wiąże tych, którzy aktualnie tworzą to samo społeczeństwo, ponieważ korporacje są nieśmiertelne; żyliśmy w naszych przodkach, a oni żyją nadal w swych potomkach"78. Bezpośrednia zgoda naocznych świadków ewoluuje więc do „cichego przyzwolenia doskonale nabierającego mocy przez zwyczaj sięgający poza pamięć człowieka"79. Dlatego koncepcja Hookera nie ma charakteru kontraktowego w tym znaczeniu, jaki przypisujemy teorii umowy społecznej, czy aktu umowy o władzę, które widzą genezę rządu w umowie określającej wzajemne uprawnienia i obowiązki stron. Choć geneza rządu jest u niego konwencjonalna, to nigdzie nie twierdzi, że dozwolenie tworzy jakiś rodzaj kontraktowej relacji pomiędzy rządzącym i rządzonymi ${ }^{80}$. Jego argumentacja przerzuca jednak pomost pomiędzy filozoficznym pozwoleniem, które stanowi podstawę legitymacji rządu, a prawomocnością jego aktualnych praktycznych działań. Dlatego tak ważna dla całego wywodu Hookera jest rehabilitacja rozumu. Jego zanegowanie i odwołanie jedynie do niezbadanej woli Boga prowadzi bowiem w konsekwencji do przekonania, że człowiek nie jest w stanie poznać dobra i zła inaczej niż tylko za pośrednictwem Słowa Bożego, Bożego prawa lub poprzez bezpośrednie objawienie. W konsekwencji nie byłby zdolny do autonomicznego (choćby w pewnym zakresie) ustanowienia dla siebie rządu i prawa, a ziemska sprawiedliwość byłaby niemożliwa. Pozwalałoby to z kolei dokonanie oceny ludzkich praw z punktu widzenia zgodności z objawieniem w sumieniu każdego człowieka, poddając władzę polityczną teologicznej ocenie ze wszystkimi tego potencjalnie wywrotowymi konsekwencjami. Hooker tymczasem zmniejsza dystans pomiędzy królestwami ludzkim i Bożym poprzez zaakcentowanie roli ludzkiego prawa i jego częściową autonomizację. Częściową, ponieważ Hooker nie przeciwstawia ich sobie, lecz wpisuje je w wielki system normatywny jako dwa niekonkurujące z sobą jego elementy. Zatem chrześcijanin, mimo upadku, zamiast pozostawać w opozycji do państwa i jego prawa na gruncie prawa Bożego, stać się może aktywną częścią wspólnoty, integralną częścią jego religijnej egzystencji, może stać się częścią prawdziwie chrześcijańskiego państwa ${ }^{81}$.

Polemizując w ten sposób wprost ze swymi purytańskimi i hugenockimi oponentami, twierdzi, że ludzie nie powinni oceniać z punktu widzenia zgodności z Pismem, czy są zobowiązani do posłuchu władzy, ponieważ:

Te rzeczy, które Prawo Boże pozostawia swobodzie i wolności, są tematem ludzkich praw pozytywnych, które to prawa dla wspólnej korzyści ograniczają wolność poszczególnych ludzi na tyle, na ile pozwalają zasady słuszności. Tak musi być, inaczej świat się przewróci i uczyni każdego swym własnym panem ${ }^{82}$.

78 I, 10, s. 248.

79 VIII, 3, s. 307.

80 W.D.J. Cargill Thompson, The Philosopher of the "Politic Society". Richard Hooker as a Political Thinker [w:] Studies in Richard Hooker...s. 41-42.

81 A.S. Mcgrade, Introduction I [w:] R. Hooker, Of the Laws of Ecclesiastical Polity, St. Martin's Press, New York 1975, s. 22-23.

82 V, 71, s. 372. 
Ponadto określenie Boga jako racjonalnego bytu, który sam wybiera przestrzeganie prawa swej własnej wewnętrznej natury, zmierzało u Hookera do wniosku, że obywatelskie nieposłuszeństwo i rebelia są nie tylko sprzeciwem wobec słusznie ustanowionego porządku społecznego, lecz także buntem przeciwko porządkowi metafizycznemu ${ }^{83}$. Przez analogię ludzie, którzy sprzeciwiają się prawom społeczeństwa, wydają się podobni do największego przykładu nieposłuszeństwa, jakim są upadłe anioły, które za sprawą pychy spadły do otchłani i odtąd nieustannie knują, by „wywołać powszechną rebelię przeciwko prawu i, o ile to możliwe, całkowite zniszczenie Bożego dzieła"84. Widać zatem, że sam Hooker zdaje sobie sprawę z konsekwencji swego wywodu, nie może jednak pójść krok dalej, wtedy bowiem stanąłby na stanowisku swoich adwersarzy i zanegował obowiązek posłuchu władzy. Stara się zatem wyjść z tego dylematu, wskazując, że większość ludzi nie jest wstanie poprzez indywidualną refleksję poznać nakazów prawa naturalnego, a przez to wskazać treści naturalnych zobowiązań. Indywidualna ocena treści prawa jest zatem zawodna i niepewna. Dla większości źródłem zobowiązania politycznego jest po prostu prawo pozytywne jako takie, bez odnoszenia go do treści prawa naturalnego, ostatecznie więc przestrzeganie prawa wypływa z nawyku wytworzonego przez taką postawę. Rozum indywidualny musi bowiem czasem ustąpić przed rozumem zbiorowym, ukształtowanym przez mądrość i doświadczenie minionych generacji ${ }^{85}$. Jego wywody w tym względzie mają pokazać ewolucyjną naturę społeczeństwa, jego prawa i porządku konstytucyjnego, a zarazem trwałość jego instytucji.

Świat - pisze więc Hooker - nie zniesie tego, gdy usłyszy, że jesteśmy mądrzejsi niż ci, którzy byli wcześniej. W tym właśnie tkwi przyczyna, dla której powinniśmy być opieszali i niechętni zmianie, bez bardzo pilnej konieczności, starożytnych Nakazów, Obrzędów i długo istniejących Zwyczajów naszych czcigodnych poprzedników ${ }^{86}$.

Ich trwanie i skuteczność są wystarczającym powodem, by bronić ich przed tymi, którzy pragną przewrócić świat do góry nogami. Jego oponenci patrzą bowiem na historię statycznie w tym sensie, że ignorując ją chcą, powrócić do praw oraz instytucji istniejących na początku i ujawnionych expressis verbis w Słowie Bożym. Wobec tego dążenie do ich restytucji prowadzi do zanegowania aktualnego status quo i uzasadnienia jego obalenia, przy jednoczesnym odrzuceniu mądrości pokoleń i ocenie oraz negowaniu instytucji wzniesionych przez niezliczone generacje. Tymczasem różne ustroje mają rozmaite wady, które są i będą zawsze złem i których żaden ludzki wysiłek nie zdoła wyeliminować ${ }^{87}$, porządek zaś nie jest dziełem świętych ignorantów, lecz „ustalany musi zostać przez ludzi, którzy, poprzez swój urząd, posiadają w tej materii doświadczenie" ${ }^{88}$.

83 L.W. Gibbs, Introduction, Book I [w:] The Works of Richard Hooker, vol. VI, part. I, s. 98.

84 I, 4, s. 214.

85 S. Wolin, Richard Hooker and English Conservatism, „The Western Political Quarterly” 1953, vol. 6, no. 1 (March), s. 36.

86 V, 7, s. 27.

87 I, 1, s. 196-197.

88 VIII, 2, s. 298. 


\section{Rekapitulacja}

Te teoretyczne rozważania pozwalają przejść Hookerowi do analizy angielskich instytucji ustrojowych i podjąć ich obronę przez zakusami purytańskich fanatyków, gdy zaraz dodaje, że „Król nie ma żadnego uprawnienia, by czynić to bez zgody Lordów i Gmin zgromadzonych w Parlamencie" 89 . Przyznać jednak należy, że jego wizja nie do końca zgadza się z praktyką polityczną i koncepcją władzy Tudorów, zwłaszcza tam, gdzie opisuje rolę Parlamentu, niemniej jednak w ogólnym wymiarze ma ona charakter legitymizujący zastany porządek prawny. $Z$ jego analizy prawa i podstaw politycznego zobowiązania wynika bowiem, że angielskie prawa są zgodne z prawem naturalnym, a źródłem ich legitymacji jest pierwotne porozumienie. Skoro konkretne rozwiązania ustrojowe są wynikiem wyboru na mocy pierwotnego porozumienia, to angielska monarchia ma na jego mocy oraz z woli Boga wystarczająca legitymację. Konkretne rozwiązania konstytucyjne nie są u Hookera definiowane jedynie przez pierwotną zgodę, określane są natomiast przez (obok prawa rozumu) prawa pozytywne, na tej zgodzie oparte. By poznać ustrój, sięgnąć należy

nie tylko pierwszego kontraktu, którego postanowień najczęściej nie znamy, lub znamy w bardzo niewielkim stopniu, lecz do tego, co nastąpiło po tym wolnym i świadomym wyborze, czy to poprzez wyraźną zgodę (którego prawa pozytywne są świadkami), czy przez milczące przyzwolenie doskonale zarejestrowane przez zwyczaj sięgający poza ludzką pamięćco

Ewolucyjny rozwój instytucji państwowych sprawia w końcu, że prawa natury zastępowane sią przez prawa pozytywne, które stają się głównym źródłem określającym prawa monarchy i wspólnoty. Ustrój każdej wspólnoty może więc ewoluować w innym kierunku, szeroko lub wąsko definiując za pomocą prawa pozytywnego konkretne kompetencje monarchy wynikające z pierwotnej zgody.

Tak właśnie Hooker widzi genezę angielskiej monarchii prawa, sławiąc mądrość przodków, którzy ustanowili królestwo,

w którym choć żaden człowiek nie jest niezależny od władzy Królów, jednakże władza Króla jest ogólnie ograniczona w ten sposób, że we wszystkich jego działaniach samo prawo jest regułą. Aksjomatami naszego monarchicznego rządu - pisze dalej - są: Lex facit regem: królewska kompetencja wykonywana sprzecznie z prawem jest nieważna; Rex nihil potest nisi quod jure potest ${ }^{91}$.

Gdy Hooker pisze o prawie, nie ma więc na myśli tylko prawa Bożego i prawa naturalnego, lecz - co najważniejsze - także prawa ludzkie. Jest więc król podporządkowany i mglistemu bądź co bądź prawu natury, i konkretnym prawom królestwa, których nie może samodzielnie zmienić ${ }^{92}$, „ponieważ prawo jest jarzmem, które na nim spoczywa; pozytywne prawa królestwa mają tu zastosowanie i powstrzymują władzę Króla"93. Jest

\footnotetext{
89 VIII, 2, s. 299.

90 VIII, 2, s. 307.

91 VIII, 2, s. 308.

92 G.R. Elton, The Tudor Constitution. Documents and Commentary, Cambridge University Press, Cambridge 1982, s. 13-14.

93 VIII, 1, s. 299-300.
} 
to możliwe, ponieważ w angielskim systemie tworzenie prawa, jak przekonuje Hooker, nie może odbyć się bez zgody Parlamentu, na mocy historycznego zadawnienia reprezentującego całą wspólnotę polityczną. Wspólnota ta istniała, zanim powstało prawo ludzkie i zanim władze objęli monarchowie. Choć więc ogólna legitymacja monarchy wywodzi się z pierwotnego porozumienia, to jego każdorazowe prawotwórcze działania Hooker uzależnia od aprobaty reprezentantów aktualnej wspólnoty, gdy pisze: „Królowie, nawet ci, którzy władzę odziedziczyli, tak naprawdę dzierżą swe uprawnienie w swym dominium, z zależnością od całego ciała politycznego, którym rządzą jako królowie"94. Widać u niego obawę przed samowolną władzą jednostki, stara się więc nadać jej wzorem swych wielkich poprzedników ${ }^{95}$ ramy i ograniczenia, gdy pisze, że w działaniach, które są właściwe dla zwierzchnictwa, królowie muszą być poddani ścisłym regułom. Podkreśla więc Hooker dwie fundamentalne zasady monarchii konstytucyjnej: zakaz arbitralnego tworzenia prawa przez króla oraz jego podporządkowanie prawom wspólnoty. „Gdzie król kieruje państwem - przekonuje - a prawo królem, tam wspólnota jest jak harfa lub dobrze nastrojony instrument, gdzie wszystkie struny są nastrojone przez jednego, który podąża za prawem tak jak za kanonami sztuki muzycznej"'96. Król posiada więc najwyższe zwierzchnictwo, jednak wykonuje je w zależności od całego ciała politycznego, którym włada, zatem - jak konkluduje Hooker - król jest major singulis universis minor ${ }^{97}$. O ile więc zwierzchnictwo należy do króla, o tyle wymaga do swych działań prawotwórczych zgody ciała politycznego, a najwyższa władza zarówno w sprawach świeckich, jak i kościelnych nie należy do żadnego z tych ciał osobno, lecz do króla w Parlamencie. To poddanie króla jarzmu prawa i oddanie działalności prawotwórczej w ręce całej wspólnoty wynika z przekonania Hookera, że proces tworzenia i zmiany prawa nie może być pozostawiony jednej osobie, lecz musi być poddany zbiorowej mądrości ludzi rozsądnych i doświadczonych, znających delikatną tkankę wspólnoty, obeznanych z historią i zwyczajami, których wiedza pozwoli na właściwy wybór środków. W ten sposób Hooker kreśli wyrafinowaną i przenikliwą teorię monarchii prawa, wyposażając ją w silny teologiczny oraz rozumowy argument, które razem tworzą system mogący z łatwością się oprzeć roszczeniom radykałów. I to niezależnie, czy pragnęliby oni odwołać się do argumentu religijnego czy historycznego. Ostatecznie więc wywód Hookera zmierza do wniosków zbieżnych z tymi, do których doszli wielcy angielscy teoretycy monarchii prawa: Fortescue, Bracton i Smitha, dostarczając jej jednak silnego teologicznego uzasadnienia i odbierając tym samym argumenty swym purytańskim adwersarzom. Rzeczywiście, po Of the Laws of Ecclesiastical Polity z ich teologicznej argumentacji nie zostało już nic, a pod rządami nowej dynastii walka z monarchią będzie się odbywać przede wszystkim za pomocą już nie narracji wywiedzionej z Biblii, lecz argumentacji prawnej obleczonej w szaty mitu starożytnej konstytucji.

94 VIII, 3, s. 305.

95 R. Eccleshall, Richard Hooker and the Peculiarities of English. The Reception of the „Ecclesiastical Polity” in the Seventeenth and Eighteenth Centuries, „History of Political Thought” 1982, vol. 2, s. 85.

96 VIII, 2, s. 308.

97 VIII, 3, s. 304.

Artykuły - Articles 
dr hab. Tomasz Tulejski

Uniwersytet Łódzki

Wydział Prawa i Administracji

Katedra Doktryn Polityczno-Prawnych

University of Lodz

Faculty of Law and Administration

Department of Political and Legal Doctrines

e-mail: ttulejski@tlen.pl

\section{Bibliografia}

A Companion to Richard Hooker, ed. T. Kirby, Brill, Leiden, Boston 2008.

Aidan N., The Panther and the Hind. A Theological History of Anglicanism, T \& T. Clark Edinburgh 1993.

Allen J.W., A History of Political Thought in the Sixteenth Century, London 1941.

Almasy R., The Purpose of Richard Hooker's Polemic, „Journal of the History of Ideas” 1978, vol., 39, s. 251-270.

Atkinson N., Richard Hooker and the Authority of Scripture, Tradition, and Reason. Reformed Theologian of the Church of England?, Paternoster Press, Carlisle 1997.

Beeke J.R., Pederson R.J., Meet the Puritans, Reformation Heritage Books, Grand Rapids 2006.

Berry B.M., Process of Speech. Puritan Religious Writing \& Paradise Lost, Johns Hopkins University Press, Baltimore 1976.

Bethell S.L., The Cultural Revolution of the Seventeenth Century, Dennis Dobson, London 1963.

Boyd M.B., Process of Speech. Puritan Religious Writing and Paradise Lost, Johns Hopkins University Press, Baltimore 1976.

Broome J., John Knox, Gospel Standard Publications, Roundwood Lane 1994.

Calvin J., Institutes of the Christian Religion, transl. F.L. Battles, Westminster John Knox Press, Luisville 2006.

Collins S.L., From Divine Cosmos to Sovereign State. An Intellectual History of the Idea of Order in Renaissance England, Oxford University Press, New York 1989.

Documents Illustrative of English Church History, wyd. H.H. Gee, W.J. Hardy, Macmillan, New York 1896.

Eccleshall R., Richard Hooker and the Peculiarities of English. The Reception of the „Ecclesiastical Polity” in the Seventeenth and Eighteenth Centuries, „History of Political Thought” 1982, vol. 2, s. 63-117.

Elazar D.J., Covenant and Commonwealth. From Christian Separation through the Protestant Reformation. The Covenant Tradition in Politics, Transaction Publisher, New Brunswick 1998.

Elton G.R., The Tudor Constitution. Documents and Commentary, Cambridge University Press, Cambridge 1982.

Faulkner R.K., Richard Hooker and the Politics of a Christian England, University of California Press, Berkeley-London 1981.

Gough J.W., The Social Contract. A Critical Study of its Development, Clarendon Press, Oxford 1957.

Hooker R., Of the Laws of Ecclesiastical Polity, Sidgwick \& Jackson, London 1973.

Hooker R., Of the Laws of Ecclesiastical Polity, St. Martin's Press, New York 1975.

Hooker R., Of the Laws of Ecclesiastical Polity. The Fifth Book, Macmillan, New York 1902.

Hunt J., Religious Thought in England in the Nineteenth Century, Gibbings \& Co., London 1896. 
Junius Brutus, A Defence of Liberty Against Tyrants. A Translation of the Vindiciae Contra Tyrannos, G.Bell \& Sons, London 1924.

Kirby T., Richard Hooker's Doctrine of the Royal Supremacy, E.J.Brill, Leiden-New York 1990.

Kirby T., Richard Hooker, Reformer and Platonist, Asgate, Aldershot 2005.

Kirby T., Richard Hooker's Theory of Natural Law in the Context of Reformation Theology, „The Sixteenth Century Journal" 1999, vol. 30, no. 3 (Autumn), s. 681-703.

Knox J., History of the Reformation in Scotland, Blackie \& Son, Glasgow 1841.

Knox J., On Rebelion, Cambridge University Press, Cambridge 1994.

Korporowicz Ł., Prawo rzymskie w orzecznictwie Izby Lordów w latach 1876-2009, Wydawnictwo UŁ, Łódź 2016.

Lake P., Anglicans and Puritans? Presbyterianism and English Conformist Thought from Whitgift to Hooker, Unwin Hyman, London Boston 1988.

Lazar D.J., Covenant and Commonwealth. From Christian Separation through the Protestant Reformation. The Covenant Tradition in Politics, Transaction Publisher, New Brunswick 1998

Lorimer P., John Knox and the Church of England: His Work in Her Pulpit and His Influence Upon Her Liturgy Articles and Parties, Kessinger Publishing, Whitefish 2004.

M'Crie T., John Knox: Containing Illustrations of the History of the Reformation in Scotland, William Balckwood, Edinburgh 1831.

Miller P., Errand into the Wilderness, Harvard University Press, Cambridge 1956.

Monahan A.P., Consent, Coercion and Limit. The Medieval Origins of Parliamentary Democracy, McGill-Queen's University Press, Kingston 1987.

Morgan E.S., Visible Saints. The History of a Puritan Idea, Cornell University Press, Ithaca 1965, s. $1-32$.

Musiewicz P., Wartość zwyczaju i tradycji w koncepcjach brytyjskich prekonserwatywnych $i$ konserwatywnych myślicieli politycznych, Annales UMCS, Sectio K: Politologia, vol. XVIII, 1/2011, s. 115-128.

Neale J.E., The Elizabethan Acts of Supremacy and Uniformity, „The English Historical Review” 1950, vol. 65, no. 256 (July), s. 304-332.

Nichols A., The Panther and the Hind. A Theological History of Anglicanism, T. \& T. Clark 1993.

Of the Laws of Ecclesiastical Polity, Sidgwick \& Jackson, London 1973.

Parris J.R., Hooker's Doctrine of the Eucharist, „Scottish Journal of Theology” 1963, vol. 16, s. $151-165$.

Passerin d'Entrèves A., Natural Law. An Introduction to Legal Philosophy, Hutchinson and Co. Ltd., London 1951.

Pearson A.F.S., Church and the State. Political Aspects of Sixteenth Century Puritanism, The University Press, Cambridge 1928.

Quinton A., The Politics of Imperfection, Faber and Faber London, Boston 1976.

Richard Hooker and the Construction of Christian Community, red. A.S. McGrade, Medieval \& Renaissance \& Studies, Tempe 1977.

Rosenthal A.S., Crown under Law, Richard Hooker, John Locke, and the Ascent of Modern Constitutionalism, Lexington Books, Lanham 2008.

Strauss L., Cropsey J., Historia filozofii politycznej, Fronda, Fundacja Augusta hr. Cieszkowskiego, Warszawa 2010.

Studies in Richard Hooker: Essays Preliminary to an Edition of His Works, ed. W.S. Hill, Press of Case Western Reserve University, Cleveland 1972.

Szlachta B., Monarchia prawa? Angielska myśl polityczna doby Tudorów, Księgarnia Akademicka, Kraków 2007.

The Works of Richard Hooker, Clarendon Press, Oxford 1820.

The Works of Richard Hooker, Medieval \& Reaissance Texts \& Studies, Binghamton, New York 1993.

Artykuły - Articles 
This Sacred History. Anglican Reflections for John Booty, wyd. D.S. Armentrout, Cowley Publications, Cambridge 1990.

White P., Predestination, Policy and Polemic. Conflict and Consensus in the English Church from the Reformation to the Civil War, Cambridge University Press, Cambridge-New York-Port Chester-Melbourne-Sydney 1992.

Wolin S., Richard Hooker and English Conservatism, „The Western Political Quarterly” 1953, vol. 6, no. 1 (March), s. 28-47.

Zaret D., The Heavenly Contract Ideology and Organisation in Pre-Revolutionary Puritanism, The University of Chicago Press, Chicago 1985. 